\title{
PLGA-Encapsulated Tea Polyphenols Enhance The Chemotherapeutic Efficacy Of Cisplatin Against Human Cancer Cells And Mice Bearing Ehrlich Ascites Carcinoma [Retraction]
}

\author{
Singh M, Bhatnagar P, Mishra S, Kumar P, Shukla Y, \\ Gupta KC. PLGA-encapsulated tea polyphenols enhance \\ the chemotherapeutic efficacy of cisplatin against human \\ cancer cells and mice bearing Ehrlich ascites carcinoma. \\ International Journal of Nanomedicine. 2015;10:6789- \\ 6809.
}

The Editor-in-Chief and Publisher of International Journal of Nanomedicine wish to retract the published article.

Concerns were raised about the possibility of image manipulation and duplication in the published article. The alleged image manipulation relates to the Western blot bands presented in:

- Figure 6A p-NF- $\kappa B$ and p-IкB- $\alpha$

- Figure 6A, Figure S3A and S3C $\beta$-actin bands

- Figure S3C Bax and Bcl-2

It was also found that images in Figure 4 (TF-NP + CDDP; EGCG + CDDP and EGCG-NP + CDDP) were duplicated from images presented in Figure 5 of the article:
Singh M, Bhui K, Singh R, Shukla Y. Tea polyphenols enhance cisplatin chemosensitivity in cervical cancer cells via induction of apoptosis. Life Sciences. 2013;93:7-16. doi: 10.1016/j.lfs.2013.02.001.

The authors were contacted but were unable to provide a satisfactory explanation for the alleged image duplication and could not supply satisfactory revisions for the article. The Director of CSIR-Indian Institute of Toxicology Research (CSIR-IITR) was contacted and was very helpful throughout our investigation. The Editor-in-Chief determined the findings and conclusions presented in the study were no longer supported.

Our decision-making was informed by our policy on publishing ethics and integrity and the COPE guidelines on retraction.

The retracted article will remain online to maintain the scholarly record, but it will be digitally watermarked on each page as "Retracted".
The International Journal of Nanomedicine is an international, peerreviewed journal focusing on the application of nanotechnology in diagnostics, therapeutics, and drug delivery systems throughout the biomedical field. This journal is indexed on PubMed Central, MedLine, CAS, SciSearch ${ }^{\mathbb{R}}$, Current Contents ${ }^{\mathbb{B}} /$ Clinical Medicine,
Journal Citation Reports/Science Edition, EMBase, Scopus and the Elsevier Bibliographic databases. The manuscript management system is completely online and includes a very quick and fair peer-review system, which is all easy to use. Visit http://www.dovepress.com/ testimonials.php to read real quotes from published authors. 